\title{
Toward Low-Cost, High-Energy Density, and High-Power Density Lithium-Ion Batteries
}

\author{
JIANLIN LI® ${ }^{1,2,4}$ ZHIJIA DU, ${ }^{1}$ ROSE E. RUTHER, ${ }^{1}$ SEONG JIN AN, ${ }^{1,2}$ \\ LAMUEL ABRAHAM DAVID, ${ }^{1}$ KEVIN HAYS, ${ }^{1}$ MARISSA WOOD,${ }^{1}$ \\ NATHAN D. PHILLIP, ${ }^{1,2}$ YANGPING SHENG,${ }^{1}$ CHENGYU MAO,${ }^{1}$ \\ SERGIY KALNAUS, ${ }^{3}$ CLAUS DANIEL, ${ }^{1,2}$ and DAVID L. WOOD III ${ }^{1,2}$ \\ 1.-Energy and Transportation Science Division, Oak Ridge National Laboratory, One Bethel \\ Valley Road, P.O. Box 2008, Oak Ridge, TN 37831, USA. 2.-Bredesen Center for Interdisciplinary \\ Research and Graduate Education, University of Tennessee, 418 Greve Hall, 821 Volunteer Blvd., \\ Knoxville, TN 37996, USA. 3.-Computer Science and Mathematics Division, Oak Ridge National \\ Laboratory, One Bethel Valley Road, P.O. Box 2008, Oak Ridge, TN 37831, USA. 4.-e-mail: \\ lij4@ornl.gov
}

Reducing cost and increasing energy density are two barriers for widespread application of lithium-ion batteries in electric vehicles. Although the cost of electric vehicle batteries has been reduced by $\sim 70 \%$ from 2008 to 2015 , the current battery pack cost $(\$ 268 / \mathrm{kWh}$ in 2015$)$ is still $>2$ times what the USABC targets $(\$ 125 / \mathrm{kWh})$. Even though many advancements in cell chemistry have been realized since the lithium-ion battery was first commercialized in 1991, few major breakthroughs have occurred in the past decade. Therefore, future cost reduction will rely on cell manufacturing and broader market acceptance. This article discusses three major aspects for cost reduction: (1) quality control to minimize scrap rate in cell manufacturing; (2) novel electrode processing and engineering to reduce processing cost and increase energy density and throughputs; and (3) material development and optimization for lithium-ion batteries with high-energy density. Insights on increasing energy and power densities of lithium-ion batteries are also addressed.

\section{INTRODUCTION}

Transportation currently consumes two-thirds of total U.S. petroleum and accounts for one-third of U.S. carbon pollution. In addition, on-road vehicles account for $85 \%$ of transportation. ${ }^{1}$ One potential strategy to decarbonize transport is use of electric vehicles (EVs) thanks to the breakthrough in battery technology. ${ }^{2}$ From 2008 to 2015 , the battery pack cost has been reduced from $\$ 1000 / \mathrm{kWh}$ to $\$ 268 / \mathrm{kWh}$ with a simultaneous increase in battery pack energy density from $\sim 55 \mathrm{Wh} / \mathrm{L}$ to $\sim 295 \mathrm{Wh} / \mathrm{L} .{ }^{3}$ Nevertheless, battery cost needs to be further reduced to at least $\$ 150 /$ $\mathrm{kWh}$ to enable battery EVs to become cost-competitive with internal combustion vehicles. ${ }^{4}$ The U.S. Advanced Battery Consortium's (USABC) targets for battery packs for electric vehicles are $\$ 125 / \mathrm{kWh}, 235 \mathrm{Wh} / \mathrm{kg}$ and $500 \mathrm{Wh} / \mathrm{L}$, by $2020 .^{5}$
Most of the battery cost comes from materials and manufacturing. Based on the BatPac model from the Argonne National Laboratory, batteries with common chemistries such as graphite and $\mathrm{LiNi}_{x} \mathrm{Mn}_{y}$ $\mathrm{Co}_{1-x-y} \mathrm{O}_{2}$ (NMC) would not meet the USABC's target even in the best-case scenario (all chemistry problems solved, unlimited performance, favorable systems engineering, and high-volume manufacturing). ${ }^{6}$ A moderate risk pathway to meet the $\$ 125 /$ $\mathrm{kWh}$ target is coupling silicon anode with a highcapacity cathode. Using lithium metal as the anode could further reduce the battery cost to $<\$ 100 / \mathrm{kWh}$, albeit at a higher risk. ${ }^{6}$ Many daunting challenges need to be addressed for silicon and lithium anodes. These include the dramatic volume changes ${ }^{7,8}$ and unstable solid electrolyte interphase $(\mathrm{SEI})^{9}$ for $\mathrm{Si}$ anodes, as well as the catastrophic failures associated with lithium dendrites forming on lithium anodes. ${ }^{10}$ Therefore, cost reduction in the near term 
could come from improvements in cell manufacturing, learning rates for pack integration, and capturing increasing economics of scales. ${ }^{11}$ Given the mass production of lithium-ion batteries (LIBs), battery recycling and minimizing environmental impact would also contribute to cost reduction.

Improving the energy density of LIBs is another challenge to increasing the limited range of EVs. For vehicles with comparable cost, the driving ranges of EVs are generally only $22 \%$ compared with vehicles with internal combustion engines. ${ }^{12}$ This challenge will remain a problem for EVs until fast recharging is realized. Electrode Engineering can reduce battery cost and improve energy density simultaneously by reducing the relative weight of inactive components such as conductive additive, binder, separator, and current collector. Another approach is using active materials with higher energy densities.

In this article, cost reduction from materials processing and cell manufacturing is discussed, specifically covering quality control during electrode manufacturing to reduce scrap rate, novel technologies for low-cost electrode manufacturing, electrode engineering for high-energy and power electrodes, and modified protocols to shorten the formation period. The relationship among microstructure, properties, and performance is also discussed. In addition, recent progress in materials for highenergy density LIBs is summarized for both anodes and cathodes. Insights on achieving low-cost and high-energy density LIBs are shared.

\section{COST REDUCTION}

\section{Quality Control}

One strategy to reduce battery cost through manufacturing is improving quality control (QC) to reduce the scrap rate. The overall scrap rate in the state-of-the-art LIB production is reported to be $\sim 2 \%{ }^{13}$ This does not include flawed or substandard electrodes in cell assembly that results in a much higher scrap rate and battery cost because of extra costs from the subsequent value-added steps such as the cell assembly and formation cycling. Current technologies used in industry to detect coating defects such as pinholes, agglomerates, nonuniform coatings, etc. are beta transmission and chargecoupled device (CCD) camera inspection. ${ }^{14}$ Other techniques like Raman spectroscopy have also been used to identify variations in coating composition during off-line material testing. ${ }^{15,16}$ These techniques are sensitive enough for certain defects like nonuniform coating and pinholes but may not have enough resolution to detect flaws like agglomerates and metal contamination in the electrode manufacturing process that lead to faulty cells being built, thereby increasing production cost.

As an alternative to the beta transmission technique, which is expensive and poses safety concerns as a result of radiation, laser calipers have been used to measure the wet thickness of the coating along a line scan. ${ }^{17}$ The in-line measurement also provides a feedback loop to adjust the coating protocol for timely error correction. This is achieved by using two sensors that emit laser light at an angle and by capturing the laser profile using a camera. The sensor calculates a corresponding voltage output that has a linear relationship with thickness. Figure 1a shows the laser caliper system mounted on the coater orthogonally to the substrate to maintain alignment when electrode thickness changes. Precision of $< \pm 2 \%$ for in-line laser measurement was achieved.

To detect defects effectively in-line on a highspeed electrode coating system, infrared (IR) thermography was employed. ${ }^{18}$ IR cameras detect the IR energy emitted from an object as a function of temperature. This system, as shown in Fig. 1b, consists of an IR camera pointed at the electrode coming out of the hot drying oven using a series of mirrors. The thermal radiation off the coating is captured by the camera and is analyzed. As electrode coatings are solid objects, with good thermal conductivity, the heat in the coating must be transferred to the surface by internal conduction and convection through pore. Coating defects tend to change the thermal response. Hence, any flaws in the coating will appear as a temperature variation at that point. In the case of pinholes (insert in Fig. 2) and nonuniform coating, there is less radiation from the coating, and in the case of agglomerates, there is more radiation.

The reduction in scrap rate and thus reduction in manufacturing cost can further be addressed by investigating the degree of correlation between different types of defects and long-term electrochemical performance of cells. If such correlation appears to be insignificant for some types of defects, the electrodes containing these defects can still be used in batteries. For that purpose, a comprehensive study has been conducted involving intentionally introduced electrode defects of different type and controlled size. ${ }^{18}$ Four types of defects were considered, chosen based on likelihood of encountering them in battery manufacturing: pinholes, agglomerates of electrode material, and areas uncoated with slurry. The latter was studied in two configurations: one uncoated stripe of $3 \mathrm{~mm}$ width and 3 uncoated stripes each $1 \mathrm{~mm}$ wide. The influence of these defects on electrochemical performance was evaluated in coin cells. Figure 2 summarizes the results of these tests along with thermal or optical images of the four types of defects. The extent of capacity fading during longterm cycling at $2 \mathrm{C}$ rate worsened in the sequence of: baseline $<1$ time large nonuniform coating $<$ pinholes $<3$ times nonuniform coating $<$ agglomerates. Microstructural analysis of agglomerates revealed carbon-rich regions that reduced the electrochemical performance during high-rate cycling. 

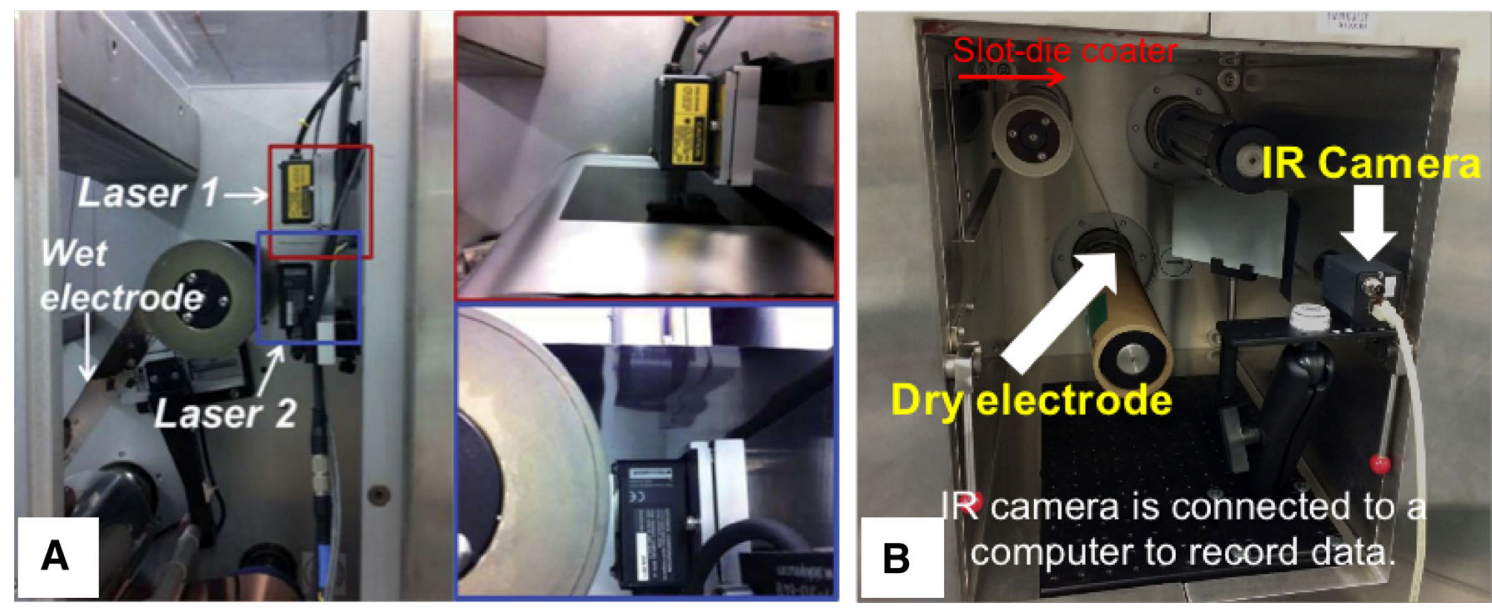

Fig. 1. Electrode coating quality control. (a) Laser caliper setup on electrode coater to measure coating thickness. (b) IR thermography setup to measure coating defects in-line. Reproduction from Ref. 17 with permission from The Royal Society of Chemistry.
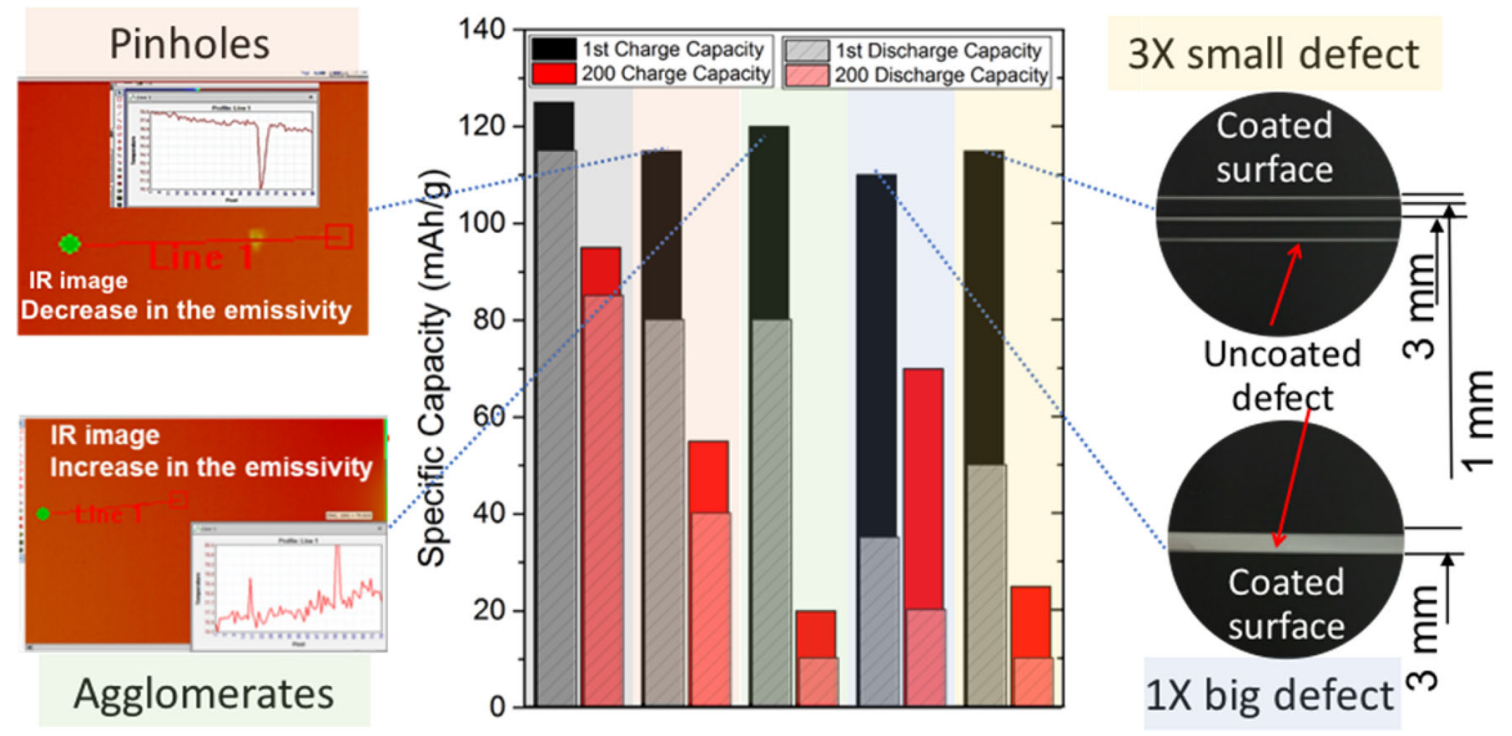

Fig. 2. Performance analysis of electrodes with coating defects when compared with the baseline. Part of the contents are reproduced from Ref. 18 with permission from Elsevier.

Observations made in this study provide a detailed in-line system for thickness measurement and coating defect identification that can be incorporated with a feedback loop to the slot-die coating system. Electrochemical analysis of these defects also provides insight into the role of these defects on cycling performance.

A new technique, active thermal scanning, has been developed recently for in-line porosity and areal loading characterization of battery electrodes. ${ }^{19}$ Compared with other techniques, e.g., porosimetry and x-ray tomography, the thermal scanning is nondestructive and compatible with high-speed, roll-to-roll manufacturing of LIB electrodes. This technique can be used for electrode coating and calendaring processes. Together, these different techniques for improved quality control will reduce the scrap rate of electrodes and will minimize the cell rejection rate after fabrication and testing.

\section{Electrode Processing}

\section{Aqueous Processing}

Although aqueous processing has been adopted in manufacturing of graphite anodes, most composite cathodes are manufactured through an organic solvent process by using polyvinylidene fluoride (PVDF) and $N$-methyl-2-pyrrolidone (NMP) as the binder and the solvent, respectively. ${ }^{20,21}$ There has been growing interest in switching cathode manufacturing from NMP-based processing to aqueous processing because of the multiple benefits: (1) lower cost in raw materials $[\$ 1.5 / \mathrm{L}$ to $\$ 3.0 / \mathrm{L}$ NMP 
versus $\$ 0.015 / \mathrm{L}$ water, $\$ 5.5 / \mathrm{lb}$ PVDF versus $\$ 1.1 / \mathrm{lb}$ carboxymethyl cellulose $(\mathrm{CMC})]^{22,23}$ and capital; ${ }^{24}$ (2) elimination of solvent recovery-up to 2 times reduction in electrode processing cost including drying and solvent recovery; ${ }^{23}$ (3) less environmental effect; ${ }^{25}$ and (4) easier siting and permitting of battery manufacturing plant. Nevertheless, replacing NMP with water also creates several processing problems: (1) agglomeration of electrode components in aqueous suspensions as a result of the strong interaction between colloidal particles; ${ }^{26}(2)$ poor wetting of aqueous suspension on $\mathrm{Al}$ foils ascribed to high surface tension of water; ${ }^{27}(3)$ metal leaching in water suspension; (4) electrode cracking attributed to high residual stress induced by surface tension of water during electrode drying; ${ }^{28}$ and (5) residual moisture removal. ${ }^{29}$

Fortunately, most of these problems are solvable and great progress has been achieved. For example, the agglomerates can be controlled by adding dispersants $^{20,26,30,31}$ or by optimizing mixing techniques, sequences, and periods. ${ }^{32-34}$ Poor slurry wetting on $\mathrm{Al}$ foils can be alleviated via increasing the surface energy of the current collectors such as treating the $\mathrm{Al}$ foils with corona plasma ${ }^{27}$ or coating with a carbon layer. Metal leaching may or may not be a problem. Figure 3 shows the $\mathrm{Li}^{+}$concentration in saturated $\mathrm{LiFePO}_{4}$ and $\mathrm{LiNi}_{0.5} \mathrm{Mn}_{0.3} \mathrm{Co}_{0.2} \mathrm{O}_{2}$ (NMC532) suspension at room temperature. Although the $\mathrm{Li}^{+}$concentration increased dramatically from one day to one week, it has been proven that the effect of lithium ion leaching on cyclability of $\mathrm{LiFePO}_{4}$ is negligible because the leached lithium ion can reintercalate into $\mathrm{LiFePO}_{4}{ }^{35}$ and commercialization of $\mathrm{LiFePO}_{4}$ cathodes via aqueous processing is ongoing. ${ }^{36}$ Lithium ion leaching in NMC532 is slightly higher than in $\mathrm{LiFePO}_{4}$ and continues to increase with higher Ni content. Nevertheless, comparable performance has been observed from NMC111 37 and NMC532 $2^{38}$ via aqueous and NMP-based processing. Cracking is induced by capillary stresses generated during drying, ${ }^{39}$ which is more likely for thick electrodes. This problem can be circumvented by reducing the surface tension of the solvent; for example water can be mixed with another solvent with lower surface tension. ${ }^{28}$ As for residual moisture removal, it is common that electrodes produced via aqueous processing have higher moisture uptake as a result of the hydrophilic nature of the water-soluble binders. The efficiency in removing the residual moisture depends on the chemistries and binders. Yet, it has been reported that the residual moisture of aqueous processed NMC532 cathodes can be easily reduced to a similar level as NMP-based processing through a routine secondary drying protocol. $^{29}$ The effect of residual moisture on electrochemical performance also depends on the chemistries, and it may not show up without longer term cycling. For example, there is no significant capacity fade in the $\mathrm{LiFePO}_{4}$ cathode with 500-ppm

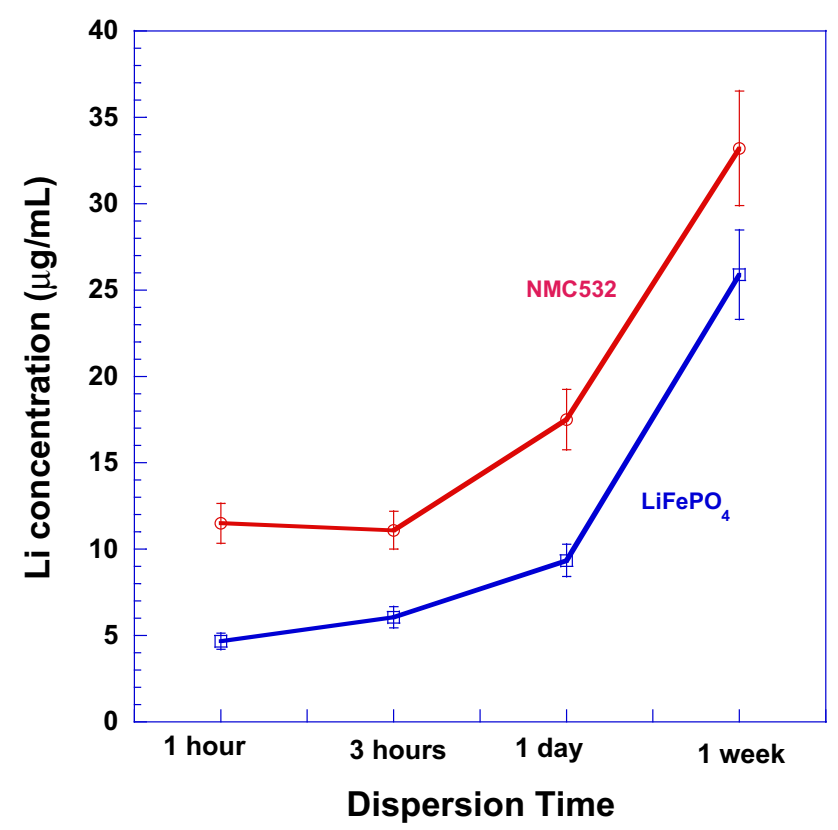

Fig. 3. $\mathrm{Li}$ ion concentration in saturated $\mathrm{LiFePO}_{4}$ and $\mathrm{NMC532}$ suspensions. The Li ion concentration of NMC532 is from Ref. 40.

moisture for 1000 cycles. ${ }^{41}$ In addition, a radiant drying process has been demonstrated to remove residual moisture effectively from $\mathrm{LiFePO}_{4}$ cathodes in 2 min compared with the conventional 18-h to $22-$ $\mathrm{h}$ drying at $80^{\circ} \mathrm{C}$ inside a vacuum oven, resulting in a 500-fold decrease in the secondary drying process and in a $68 \%$ reduction in energy consumption. ${ }^{41}$ The radiant drying could be an effective technique for secondary drying of aqueous-processed electrodes.

Although there is no concern of volatile organic compounds (VOCs) in aqueous processing, adequate amounts of water are needed to dissolve water soluble binders and to keep the slurry at desirable viscosity for electrode coating, which could be energy intensive during electrode drying. Energy curing provides an option toward solventless coating where low-molecular-weight (MW) polymers/ oligomers or monomers are cured into cross-linked, high-molecular polymers instantly under electron beam (EB) or ultraviolet light (UV). ${ }^{42}$ Compared with thermal oven drying, energy curing provides three benefits: (1) less space needed by the UV/EB unit enabling a reduced footprint, (2) lower energy consumption for UV/EB unit, and (3) high throughputs ascribed to the fast curing speed from UV/EB technology. Compared with UV curing, EB curing does not need photoinitiators and has greater penetration depth, which is adjustable from the accelerating voltage of the electron beam. ${ }^{43}$ The basic concept has recently been proven that low MW oligomers are used in the slurry preparation and high MW crosslinked polymers are obtained from EB curing at high line speeds. ${ }^{40}$ 
It has been demonstrated that the NMC532 cathode was successfully fabricated using an EBcured acrylated polyurethane (PU) binder. ${ }^{40}$ The electrochemical performance was comparable with that in conventional NMP-based processing. The first charge capacities of electrodes using PVDF and EB-cured acrylated PU as binders are $179 \mathrm{mAh} / \mathrm{g}$ and $178 \mathrm{mAh} / \mathrm{g}$ with Coulombic efficiencies of $84 \%$ and $85 \%$, respectively. The similar overlapping of the differential capacity curves indicates that the EB-cured polymer functions identically to the PVDF binder, which does not affect the electrochemical reactions of $\mathrm{Li}^{+}$intercalation/de-intercalation into the NMC particles. After 100 cycles, the NMC532 cathodes via NMP-based processing and EB curing delivered $157 \mathrm{mAh} / \mathrm{g}$ and $153 \mathrm{mAh} / \mathrm{g}$ in discharge capacity, respectively, where the variation was within experimental error. This demonstrates that similar cyclability can be achieved by using the EB curing process compared with the conventional NMP-based processing. ${ }^{40}$ This novel processing approach presents a promising new avenue for mass manufacturing of high-performance, low-cost Li-ion batteries. Further R\&D activity on highspeed scaling up is currently continuing at Oak Ridge National Laboratory.

\section{Shortening Formation Period}

Electrolyte wetting and solid electrolyte interphase (SEI) formation are the slowest processing steps in cell assembly and take between 1 and 3 weeks depending on the cell chemistry and manufacturer. This is a result of slow electrolyte wetting and low C-rates (e.g., three to five charge-discharge cycles with typically $\mathrm{C} / 20$ rates at research laboratories and slightly higher at industry sites). The processes cost is about $\$ 23 / \mathrm{kWh}$, which is the second most expensive after the electrode processing cost $(\$ 36 / \mathrm{kWh}){ }^{22}$ Large equipment space and high energy are also necessary to maintain production rates because all cells have to be placed in environmental chambers (typically between $30^{\circ} \mathrm{C}$ and $60^{\circ} \mathrm{C}$ ) and connected to cyclers. Hence, it is beneficial to reduce formation time and steps without compromising the cell performance to realize cost reduction.

The SEI forms on the anode when the electrolyte is reduced at low potentials, typically below $0.9 \mathrm{~V}$ versus $\mathrm{Li} / \mathrm{Li}^{+}$for ethylene carbonate (EC) and $0.75 \mathrm{~V}$ versus $\mathrm{Li} / \mathrm{Li}^{+}$for propylene carbonate (PC). ${ }^{44,45}$ Some additives in the electrolyte can decompose and precipitate on the anode at a higher voltage. For example, vinylene carbonate (VC) has lower activation energy for reduction $(13 \mathrm{kcal} / \mathrm{mole})$ compared with EC $(25 \mathrm{kcal} / \mathrm{mole})$ or PC $(26 \mathrm{kcal} /$ mole). VC decomposes and precipitates (forms SEI) around $1.4 \mathrm{~V}$ versus $\mathrm{Li} / \mathrm{Li}^{+}$. ${ }^{46}$ Hence, during a charge cycle, VC precipitates first on the anode and becomes a part of the SEI structure followed by EC (or PC). The reduction potentials increase at an elevated temperature and vary depending on anode (graphite) surface chemistry (e.g., amount and kind of electron donor groups) and structure (e.g., basal plane surface or edge surface).

Having stable SEI layers on an electrode is necessary because most common commercial, carbonate-based electrolytes are not stable and decompose irreversibly at a high state of charge (e.g., reduction reactions below $0.9 \mathrm{~V}$ versus $\mathrm{Li} / \mathrm{Li}^{+}$at anode and oxidation reactions above $4.2 \mathrm{~V}$ versus $\mathrm{Li} / \mathrm{Li}^{+}$at cathode). An SEI layer prevents an electrolyte from irreversible reduction reactions (decompositions) by hindering (ideally blocking) electron transfers between an electrode and the electrolyte while allowing lithium ion diffusion through the SEI layer. Because a pristine electrode does not have SEI layers that prevent the electron transfers, most SEI forms during the first chargedischarge cycle. Irreversible capacity loss resulted from SEI formation dramatically decreases after the first cycles because of the preformed SEI layers that passivate electrode surfaces. Once SEI forms properly, it insulates the electrode electronically and prevents electrolyte consumption and loss of lithium inventory. The proper SEI should have negligible electrical conduction, high lithium ion selectivity and permeability, stability in electrolyte, stability/ flexibility in volume changes of active materials (graphite, Si, Sn, etc.), and thermal stability. To this end, it is typically a slow process (e.g., multiple cycles at $\mathrm{C} / 20$ or $\mathrm{C} / 10$ ) to form a proper SEI on electrodes, which causes slow production speed and consequently adds extra cost to LIBs.

It is challenging to reduce the SEI formation time without sacrificing cell performance. A few studies have been attempted to shorten the SEI formation time. Increasing the C-rate is a simple method for that purpose, but it can cause nonuniform and discontinuous SEI. ${ }^{47,48}$ An alternative is reducing the upper cutoff voltages during formation cycles at the expense of high-capacity fade. ${ }^{49}$ Meanwhile, a new protocol has been developed recently where shallow charging-discharging at high state-ofcharge was attempted and superior capacity retention was maintained while reducing the formation time by $\sim 6$ times and impedance of the cells as shown in Fig. $4 .^{50}$ The shallow charging-discharging method involved repeated cycling a few times between $3.9 \mathrm{~V}$ and $4.2 \mathrm{~V}$ (cell voltage) after the first charge. Then, a full discharge took place at the final cycle. Further time reduction seems to be feasible when the method is optimized.

SEI formation is not only affected by the C-rate but also by the surface properties of active materials. To have a uniform SEI layer on an electrode, electrolyte has to be distributed uniformly before the first charge. Complete electrolyte wetting of small pores is slow especially in a large cell. One common effective method to provide accelerated and uniform wetting is to apply a vacuum during cell sealing. Electrode surface properties determine interactions between the electrodes and 

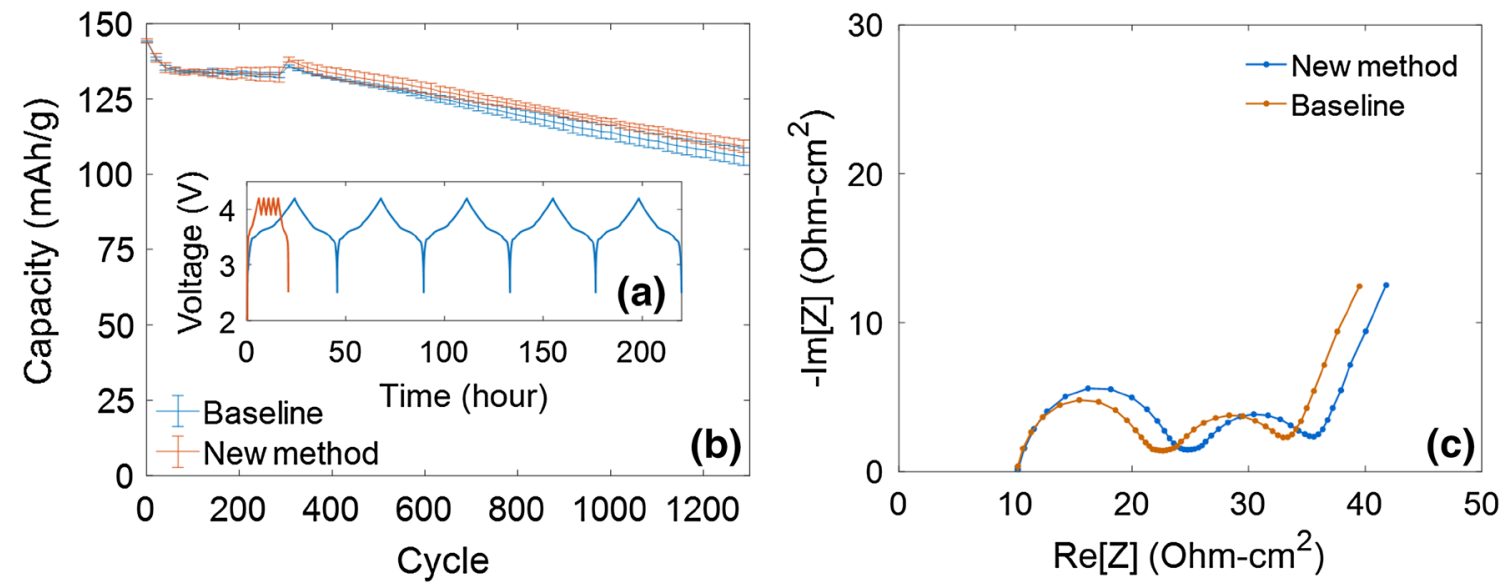

Fig. 4. Voltage profiles of baseline cell and cells cycled with a new method for SEl formation cycles (a); capacities during 1300 cycles at $1 \mathrm{C}$ charge and discharge rates after each formation cycle (b) and cell impedances after the 1300 cycles (c).

electrolytes, which impacts electrolyte wetting and reduction potentials and, eventually, SEI formation. ${ }^{46,51-53}$

There have been several studies on modifying graphite surfaces such as heat and acid treatment to control surface chemistry (e.g., oxygen and nitrogen). ${ }^{54-58}$ Nitrogen or oxygen on graphite surfaces can interact more with $\mathrm{Li}^{+}$in electrolyte because their electron density is high. Heat treatment in an inert environment can reduce oxygen from the graphite surface. The graphite with low oxygen contents experienced exfoliations resulting from poor SEI formation. ${ }^{59,60}$ Chemical treatment such as $\mathrm{HNO}_{3}$ and $\left(\mathrm{NH}_{2}\right)_{2} \mathrm{~S}_{2} \mathrm{O}_{8}$ increases oxygen levels on graphite surfaces, which resulted in better reversible capacity. ${ }^{61}$ Ultraviolet light treatment also has been used to reduce the oxygen level on graphite anodes and has resulted in higher capacity retentions and lower impedances as shown in Fig. 5. ${ }^{62}$ The results of these studies seem to suggest that there are optimum levels or types of oxygen on electrodes although their exact functions in the wetting and SEI formation are not well understood yet.

\section{ELECTRODE ENGINEERING}

Optimizing cell engineering is a straightforward approach to increase the cell energy density by increasing the volume ratio of active materials in a battery pack. Numerical modeling has been applied to understand the electrochemical system for cell engineering. The operation of a LIB follows porous electrode theory and electrochemical reaction thermodynamics. Newman et al. developed the governing equations. ${ }^{63,64} \mathrm{LiFePO}_{4}$ and NMC thick electrodes have been optimized by a combined experimental and simulation approach. ${ }^{65,66}$ Efforts have been put forth in a variable porosity electrode, but this has only led to marginal improvements in energy density compared with well-designed constant-porosity electrodes, suggesting it is more important to decrease the tortuosity. ${ }^{6}$
Numerical simulation has also been applied to investigate the limiting factors of the energy-power density relationship in $\mathrm{LiNi}_{0.8} \mathrm{Co}_{0.15} \mathrm{Al}_{0.05} \mathrm{O}_{2}$ (NCA)/ graphite cells with thick electrodes. ${ }^{68}$ Lithium ion depletion in the electrolyte and lithium diffusion gradient in active material particles were found to attenuate the advantage of thick electrodes. The limiting factors were more profound with increasing C-rates. Several different porosity gradients were also modeled to determine the improvement of energy density. Figure 6a shows the gradients with four linear (i-iv) and six second-polynomial ( $\mathrm{v}-\mathrm{x}$ ) variations. Figure $6 \mathrm{~b}$ shows the energy density of the cell stack with a $150-\mu$ m-thick cathode under a $1.5 \mathrm{C}$ discharge rate. Although four gradients have higher energy density than the baseline, the improvement is not significant. Nevertheless, poor porosity gradient design can decrease the energy density, as shown by porosity gradient (v) because the electrolyte depletion gets worse. ${ }^{68}$ It is noted that the lithium ion diffusion length is estimated with the Bruggeman relation, which is based on the assumption of a low-volume fraction of insulating phase represented by random, isotropic spheres. The actual electrode structure is more complex where the Bruggeman relation may be invalid, ${ }^{69}$ and the actual cell performance could be different from the simulation results.

Li-ion diffusion in the active materials is usually multiple orders of magnitude slower than in common liquid electrolytes and, thus, becomes the ratelimiting step in power performance for thin electrodes. Nevertheless, the Li-ion transport limitations in liquid electrolytes become increasingly important as the electrode thickness increases ${ }^{67,68,70,71}$ because the diffusion time in the liquid phase is no longer negligible as a result of the significant increase in diffusion length in the thick porous electrodes. Consequently, it is necessary to design thick electrode architectures to take advantage of the increased energy density provided by the higher active material volume ratio, while 

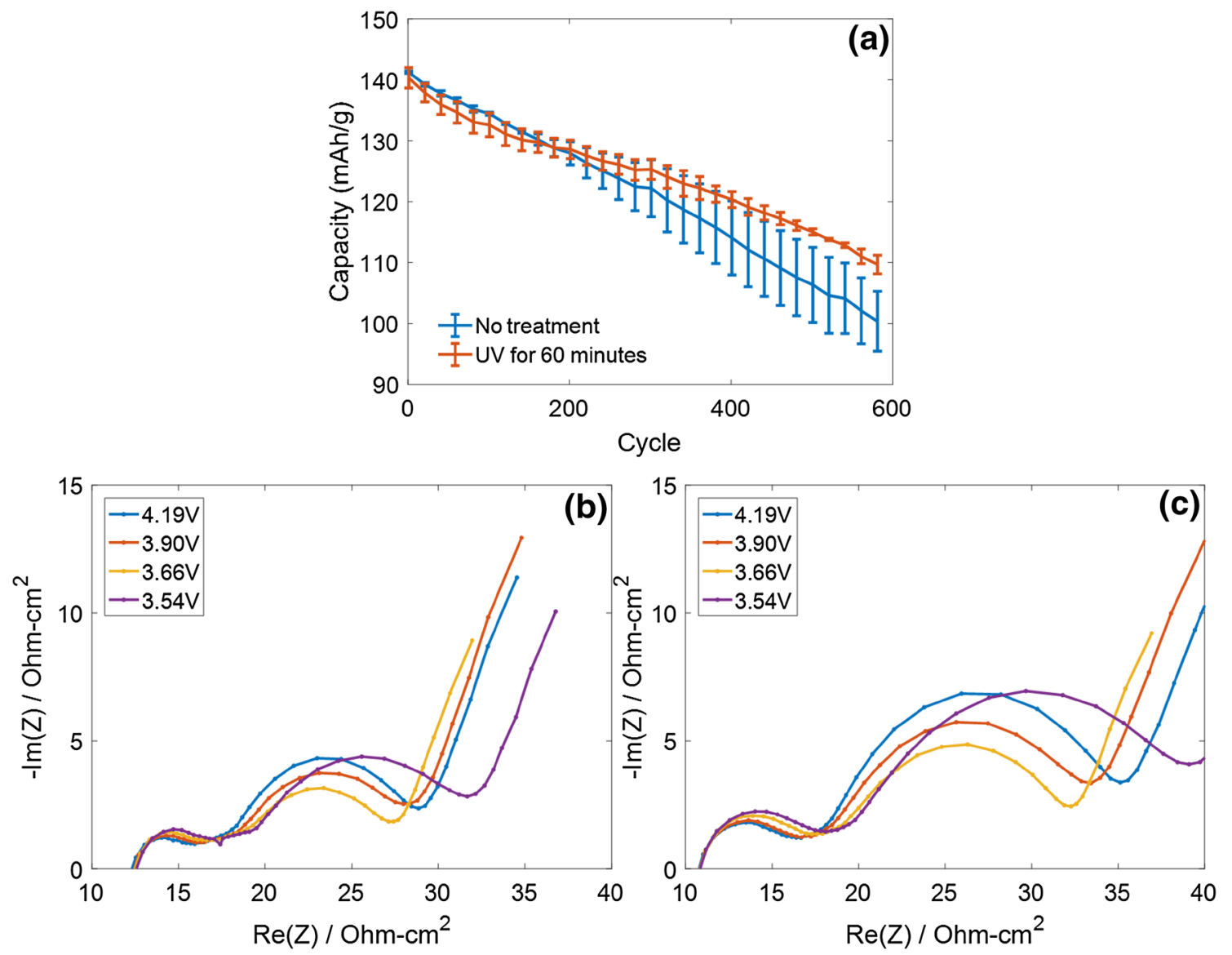

Fig. 5. Capacities during 600 cycles at $1 \mathrm{C}$ charge and discharge rates with/without ultraviolet light treatment before the cycling (a); impedance from treated sample (b) and no-treated sample (c) after 300 cycles.
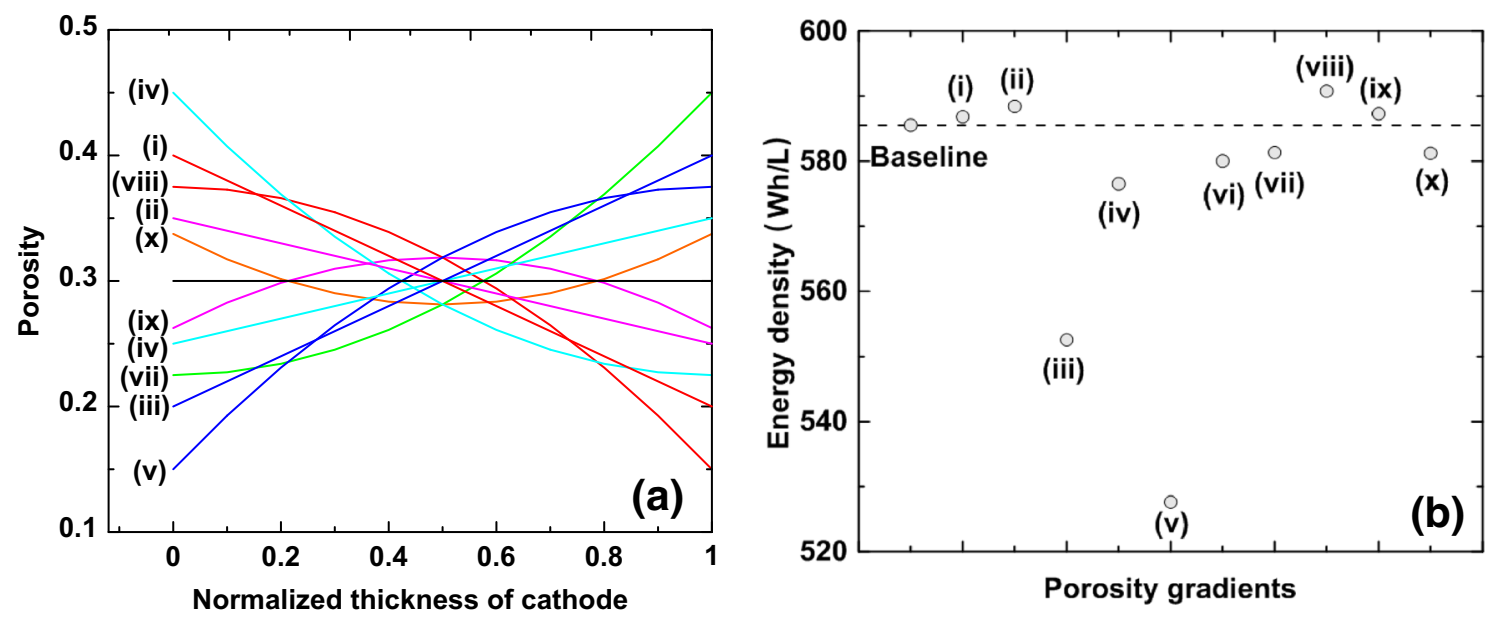

Fig. 6. (a) Porosity gradients design along cathode thickness direction with linear variations (i-iv) and second nominal variations ( $v-x)$; (b) Energy density of cell stacks with $150-\mu$ m-thick cathodes under $1.5 \mathrm{C}$ discharge when different porosity gradients are used. ${ }^{68}$ Reproduction from Ref. 68 with permission from Springer.

minimizing the tortuosity and transport limitations that can be detrimental to power performance. Many different designs have been suggested, including graded-porosity and hierarchical architectures, ${ }^{67,72-76}$ and several simulations have shown that smaller active material particles can help decrease the polarization and capacity loss observed at high discharge rates by shortening the Li-ion diffusion path in the particles. ${ }^{68,71,77}$ Yet, particle size variations also affect the packing structure of 
the electrode and can result in different pore sizes and distributions, as well as in differences in the contact resistance between the electrode and the current collector. These variations could be leveraged to improve transport properties and battery performance. Multilayer architectures have been proposed to balance the potential advantages of different particle sizes. Tuning the electrode architecture using parameters such as particle size could enable flexible cell optimization to meet the requirements of different applications. The multilayer architectures can be created by separate coatings or simultaneous coatings that allow various electrode components or formulations in each layer for a specific purpose. ${ }^{78}$ For example, the bottom layer could have higher binder content to account for binder migration during electrode drying and maintain good adhesion between the electrode and the current collector.

Tortuosity can also be minimized by using spherical particles and obtaining a homogenous electrode structure ${ }^{79}$ which could be realized with monodisperse particles. Nonspherical particles, such as graphite, result in heterogeneous structures where tortuosity is anisotropic. ${ }^{69}$ Aligning the direction with the lowest tortuosity perpendicular to current collector will benefit $\mathrm{Li}$-ion diffusion from bottom to top layers. Another method to reduce tortuosity is through electrode processing. Introducing a pore former that can be well controlled and eliminated during electrode drying or sintering step is one effective method to create straight channels (where tortuosity is 1) in electrodes ${ }^{72,80}$ The straight channels can also be created by laser structuring, ${ }^{81}$ coextruded electrodes with a low-density area besides a higher density area, ${ }^{82}$ or $3 \mathrm{D}$ printing interdigitated electrodes. ${ }^{83}$ Nevertheless, better understanding on current distribution and its effect on lithium plating is needed for these special structures. They could also increase manufacturing cost.

\section{PROGRESS IN HIGH-ENERGY MATERIALS}

\section{High-voltage Cathode Materials}

Besides electrode engineering, another effective way to increase the energy density of LIBs is to use electrode materials with high-energy density. Graphite anodes used in commercial LIBs can achieve a reversible capacity $>360 \mathrm{mAh} / \mathrm{g}$, close to the theoretical value of $372 \mathrm{mAh} / \mathrm{g}$ for $\mathrm{LiC}_{6} \cdot{ }^{84-86}$ By contrast, even the best commercial cathodes are limited to gravimetric capacities around $200 \mathrm{mAh} / \mathrm{g} .{ }^{85,87}$ The cell voltage is also limited by the choice of cathode. Thus, there has been intense interest in developing high-capacity, high-voltage cathodes to increase the specific energy of LIBs. ${ }^{88,89}$ Additionally, cathode materials must meet several other design criteria including electrochemical and thermal stability, abuse tolerance, reasonable cost, good electronic conductivity, and high-rate capability.
The first commercial LIB introduced by Sony in 1991 used $\mathrm{LiCoO}_{2}$ for the cathode active material. Prepared at a high temperature, $\mathrm{LiCoO}_{2}$ adopts a layered structure with the $R \overline{3} m$ space group (Fig. 7) ${ }^{90,91} \mathrm{LiCoO}_{2}$ is limited to a reversible capacity of $140 \mathrm{mAh} / \mathrm{g},{ }^{92}$ but layered oxides with significantly higher capacity are achieved through partial substitution of Co with other metal ions (Fig. 7) ${ }^{93-95} \mathrm{In}$ particular, Ni-rich NMC cathodes $\left(\mathrm{LiNi}_{x} \mathrm{Mn}_{y}\right.$ $\mathrm{Co}_{1-x-y} \mathrm{O}_{2}$ where $\mathrm{x}>0.6$ ) with reversible capacities $>200 \mathrm{mAh} / \mathrm{g}$ show great promise for increasing the energy density in Li-ion cells and are likely to replace lower capacity chemistries for the next generation of electric vehicles. ${ }^{96,97}$ Nonetheless, several outstanding challenges with Ni-rich NMCs must be addressed. High-voltage cycling $(>4.4 \mathrm{~V})$ will be required to achieve a cell-level energy density $>250 \mathrm{Wh} / \mathrm{kg}$, even if the NMC cathode is paired with an advanced anode such as silicon-graphite composites. ${ }^{98}$ High-voltage cycling results in impedance rise and capacity loss. ${ }^{99}$ The impedance rise is partly attributed to a rock-salt surface reconstruction layer resulting from oxygen loss and reduction of the transition metal oxidation states. ${ }^{100}$ Also, high-voltage cycling results in decomposition of current generation electrolytes and in the buildup of a surface reaction layer. ${ }^{99,100} \mathrm{Ni}^{4+}$, in particular, is not stable in contact with electrolyte. ${ }^{100,101}$ This complex interplay among electrolyte degradation, phase changes, and transition metal dissolution from the cathode surface have spurred investigations of the cathode electrolyte interface (CEI) in recent years. ${ }^{102}$ Electrolyte decomposition products deposit on the cathode surface in the form of $\mathrm{Li}_{2} \mathrm{CO}_{3}, \mathrm{LiOH}, \mathrm{LiF}, \mathrm{Li}_{x} \mathrm{POF}_{y}$, polycarbonates, and species specific to electrolyte and cathode compositions. ${ }^{103,104}$ Strategies to improve the surface properties include doping, ${ }_{105}$ surface coatings, ${ }^{106,107}$ and electrolyte additives. ${ }^{108}$ These approaches typically result in trade-offs of maximum specific capacity and first cycle coulombic efficiency ${ }^{109}$ for decreased impedance rise, thermal stability, and reduced CEI buildup to increase cell-cycle life. ${ }^{110}$

One especially promising approach to reduce surface reactivity and prolong the cycle life of $\mathrm{Ni}$ rich NMCs is the development of compositionally graded cathodes with less $\mathrm{Ni}$ at the surface. ${ }^{96,106,107,112,113}$ These particles typically have a $\mathrm{Mn}$-rich surface and a Ni-rich core. $\mathrm{Mn}^{4+}$ is electrochemically inactive. Therefore, the Mn-rich surface stabilizes the electrode/electrolyte interface, whereas the Ni-rich core enables a high capacity and energy density. Cathodes with a Mn-rich surface also have greater thermal stability compared with their homogenous counterparts. ${ }^{114}$ Ultimately, a combination of approaches will likely be needed to produce Ni-rich NMCs with optimum performance. For example, Al-doping ${ }^{115,116}$ and surface coating ${ }^{106,117}$ are two strategies that have been used to boost capacity retention and improve rate performance in NMCs with concentration gradients. 


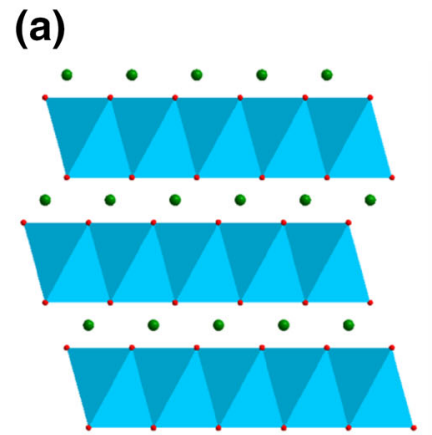

\begin{tabular}{cccc} 
& (b) Cathode Chemistry & $\begin{array}{c}\text { Capacity } \\
\text { (mAh/g) }\end{array}$ & $\begin{array}{c}\text { Average Voltage } \\
\text { (V vs. Li/Li+) }\end{array}$ \\
\cline { 2 - 4 } & $\mathrm{LiCoO}_{2}$ & 140 & 3.8 \\
& $\mathrm{LiNi}_{1 / 3} \mathrm{Mn}_{1 / 3} \mathrm{Co}_{1 / 3} \mathrm{O}_{2}$ & 160 & 3.7 \\
& $\mathrm{LiNi}_{0.6} \mathrm{Mn}_{0.2} \mathrm{Co}_{0.2} \mathrm{O}_{2}$ & 180 & 3.7 \\
& $\mathrm{LiNi}_{0.8} \mathrm{Mn}_{0.1} \mathrm{Co}_{0.1} \mathrm{O}_{2}$ & 200 & 3.7 \\
$\mathrm{MO}_{6}$ & $\begin{array}{c}0.5 \mathrm{Li}_{2} \mathrm{MnO}_{3} \bullet 0.5 \mathrm{LiMO} \mathrm{MO}_{2} \\
(\mathrm{M}=\mathrm{Mn}, \mathrm{Ni}, \mathrm{Co})\end{array}$ & 230 & 3.6
\end{tabular}

Fig. 7. Crystal structure of layered oxide cathodes. Lithium is shown between layers of $\mathrm{MO}_{6}$ octahedra (a). $\mathrm{M}$ is typically a transition metal such as $\mathrm{Mn}, \mathrm{Ni}$, or Co. Capacity and average voltage for different layered oxide cathodes (b). ${ }^{92,97,111}$

Li-rich NMCs $\quad\left(x \mathrm{Li}_{2} \mathrm{MnO}_{3} \cdot(1-x) \mathrm{LiMO}_{2}\right.$ where $\mathrm{M}=\mathrm{Mn}, \mathrm{Ni}, \mathrm{Co})$ have also attracted significant attention because they offer a very high capacity $(>250 \mathrm{mAh} / \mathrm{g})$ at high voltage $(2.5-4.7 \mathrm{~V}){ }^{111,118} \mathrm{Li}-$ rich NMCs are considered either a solid solution or a composite of $\mathrm{Li}_{2} \mathrm{MnO}_{3}$ (monoclinic structure, $C 2 / m$ space group) and $\mathrm{LiMO}_{2}$ (trigonal structure, $R \overline{3} \mathrm{~m}$ space group). ${ }^{119-121}$ Despite their promise, these cathodes suffer from first cycle irreversible capacity loss, impedance rise during high-voltage cycling, and most importantly, a significant drop in the voltage profile (voltage fade) with cycling. ${ }^{122}$ The voltage fade has been attributed to chemical and structural changes including oxygen evolution, $\mathrm{Ni}$ and Co migration from the surface into the bulk, reduction of $\mathrm{Mn}^{4+}$ to $\mathrm{Mn}^{3+}$, and formation of a spinel-like phase. ${ }^{123-129}$ The spinel-like phase is formed by the migration of lithium ion from octahedral lithium site to tetrahedral lithium site and migration of TM ions from octahedral $M$ site to octahedral lithium site via oxygen vacancies. Therefore, strategies to mitigate phase change are to restrict the cation migration. The phase change also results in a somewhat more complex CEI formation mechanism than that of Ni-rich NMC. ${ }^{130,131}$ Strategies to stabilize the surface of Li-rich NMCs include coatings ${ }^{132-135}$ surface treatments, ${ }^{126}$ cycling protocols, ${ }^{136}$ synthesis routes, ${ }^{137,138}$ and electrolyte additives. ${ }^{135}$ Most of these efforts have failed to stop the underlying mechanisms responsible for voltage fade ${ }^{135}$ although compositions that incorporate small amounts of spinel domains into the layered structure show some promise. ${ }^{139}$ Even if the structure cannot be stabilized, Li-rich NMCs with $10-30 \% \mathrm{Li}_{2} \mathrm{MnO}_{3}$ may still find use in applications where some voltage fade is acceptable or as part of cathode blends.

Moving beyond layered transition metal oxides, cathode materials capable of multielectron redox reactions are another approach to increase capacity. ${ }^{140}$ Candidates include sulfur cathodes, ${ }^{141}$ materials that undergo conversion reactions such as $\mathrm{FeF}_{3}{ }^{142}$ organic electrodes, ${ }^{143}$ disordered materials, ${ }^{144,145}$ and several polyanionic chemistries. ${ }^{146}$ Although these emerging cathodes hold promise, they face many obstacles to commercial success. No clear winner has replace layered transition metal oxides (such as NMCs) for the future generation of Li-ion batteries. Regardless of the cathode chemistry, new electrolytes or more effective additives will be required to push cell voltages beyond $4.4 \mathrm{~V} .^{44,45}$

\section{High-Energy and High-Power Density Anodes}

High-energy density cathodes must be matched with equally high-energy anodes. Although traditional graphite-based anodes already offer a specific capacity nearly twice that of the best cathode materials on the market, replacing graphite with higher capacity materials would still allow for thinner and lighter anodes, thus, resulting in higher energy density batteries. Graphite electrochemically reacts with $\mathrm{Li}$ through intercalation to form $\mathrm{LiC}_{6} \cdot{ }^{147}$ Alternatively, elements such as $\mathrm{Si}$ and $\mathrm{Sn}$ can electrochemically alloy with $\mathrm{Li}$ to form $\mathrm{Li}_{15} \mathrm{Si}_{4}{ }^{148}$ and $\mathrm{Li}_{17} \mathrm{Sn}_{5},{ }_{149}$ with much greater specific capacities of $3579 \mathrm{mAh} / \mathrm{g}$ and $960 \mathrm{mAh} / \mathrm{g}$, respectively. At first glance, the capacities of these alloying materials are very attractive, but they generate a unique set of challenges deterring manufacturers from large-scale implementation.

As opposed to graphite, which only expands $10 \%$ because of $\mathrm{Li}$ intercalation, ${ }^{150} \mathrm{Li}$ alloys such as $\mathrm{Si}$ can balloon $300 \%$ in size to accommodate the additional Li. ${ }^{151}$ Large volume changes between a charged and a discharged state quickly results in mechanical degradation, which leads to a loss in the electronic and ionic pathways to the active material of the anode. ${ }^{152}$ Thus, nano $\mathrm{Si}$ is usually used to alleviate particle pulverization. Moreover, confining the $\mathrm{Si}$ particle size to the nano domain helps alleviate stress on the electrode by distributing expansion of the particles throughout the entire electrode framework. ${ }^{153}$ Using the alloying nanoparticles alone is not sufficient as they have the tendency to agglomerate and ripen during cycling. ${ }^{154}$ Rather, composites of Si and C are used, preventing agglomeration of the nanoparticles while subsequently increasing the electronic 
conductivity. The most simplistic approach to this is achieved by mixing small quantities of Si nanoparticles with graphite electrodes. A 30-wt.\% Si/graphite composite results in a theoretical specific capacity of $1330 \mathrm{mAh} / \mathrm{g}$. When the capacity is restricted to $500 \mathrm{mAh} / \mathrm{g}$, these composites operate reliably up to 90 cycles. ${ }^{155,156}$ More complex nano Si architectures using carbon nanotubes, ${ }^{157}$ graphene, ${ }^{158,159}$ and other carbon or oxide supports $^{7,160,161}$ have also been developed and shown excellent capacity retention, but these have been synthesized only on the laboratory scale and further scale-up could be costly. In addition, the low areal loading along with the nano $\mathrm{Si}$ architectures results in low-volumetric energy density. Further extending the cycle life of Si anodes also relies on forming a stable SEI that must be sustained throughout cycling. Fluorinated ethylene carbonate (FEC) has been employed as an additive to form a more robust SEI, ${ }^{162}$ but the jury is still out as it is likely consumed during cycling, resulting in long-term capacity fade. ${ }^{163}$

Despite significant progress, many challenges remain unsolved such as cycle life. Most results in literature are from half cells where there is abundant lithium. Sufficient cycle life in full cells with high Si content anodes has not been demonstrated. Overall, the application of $\mathrm{Si}$ in lithium-ion batteries is still limited to low $\mathrm{Si}$ content and electronic devices that do not require a long cycle life. A major breakthrough in passivating $\mathrm{Si}$ surface is needed to meet the 1000 deep charge/discharge cycles. Besides the aforementioned material problems, other factors could also affect the application of $\mathrm{Si}$ in EVs, including the high cost of nano $\mathrm{Si}$, the complexity in electrode manufacturing with Si addition, challenges in cell and pack design to accommodate the significant volume expansion, and modification to the battery management system to accounts for the different voltage of $\mathrm{Si}$ from graphite.

Other alloys such as $\mathrm{Ge}^{164}$ and $\mathrm{Sn}^{165}$ have also been investigated for high-energy and high-power density anode materials. Nevertheless, similar challenges to $\mathrm{Si}$ remain including significant volume expansion and capacity fade.

\section{CONCLUSION AND OUTLOOK}

After the $\sim 70 \%$ cost reduction in lithium-ion batteries that began in 2008, further breakthroughs in material development and cell manufacturing have been required to meet the ultimate USABC targets of $\$ 100 / \mathrm{kWh}$ to $\$ 125 / \mathrm{kWh}$ for advanced electric vehicle batteries. The interrelationship between new materials integration and new cell and electrode processing methods is critical to meeting the cost and performance targets. Cell gravimetric and volumetric energy densities must also be increased by a factor of $2.0-2.5$ from $180 \mathrm{Wh} /$ $\mathrm{kg}$ to $220 \mathrm{Wh} / \mathrm{kg}$ and $300-400 \mathrm{Wh} / \mathrm{L}$, respectively, to achieve electric vehicle driving ranges that are acceptable to the public. This combination translates into a 5- to 6-time cost-energy factor that industry must still realize. Next-generation materials such as Si-based composite anodes and Ni-rich, high-voltage composite cathodes must be combined with low-cost, environmentally responsible production methods such as aqueous electrode processing or electron beam curing. Surface coatings may also play a pivotal role in both performance and processing of anode and cathode active materials. For example, o enable aqueous processing of Ni-rich NMC cathodes, a surface coating may be needed to prevent $\mathrm{Li}$ and $\mathrm{Ni}$ leaching that also benefits a longterm capacity fade.

Sophisticated electrode architecture designs, that have been successfully used in other electrochemical applications, such as polymer electrolyte fuel cells and redox flow batteries, must be implemented to realize the 15-20\% energy density improvements possible with high-loading electrodes $\left(5-6 \mathrm{mAh} / \mathrm{cm}^{2}\right.$ and higher). Thick electrodes with graded architectures have the added advantage of being able to be combined with any electrochemical couple, as well as with high-speed coating methods such as UV and electron-beam curing. Nondestructive evaluation that goes beyond the current optical camera and beta gauge techniques will also need to be combined with next-generation production lines and electrochemical couples that raise electrode production yield to $\gg 99 \%$. The combined cost reduction, highenergy density, and high-power density will likely come from parallel advances in the following specific areas:

1. Solving the challenges of implementation of high-energy anode and cathode active materials such as high-capacity fade and surface and structural changes

2. Development of high-voltage electrolytes

3. Periodic revival/maintenance of batteries allowing smaller batteries to meet the driving range and cycle life requirement

4. Improved quality control and nondestructive evaluation methods to reduce the scrape rate

5. Porous current collectors or eliminating current collectors to increase the energy density of batteries

6. Novel electrode manufacturing techniques such as high-speed curing methods with low solvent content or dry/solventless coating

7. Improved Li-ion transport for simultaneous high-energy and high-power batteries. High Liion transport will be achieved by highly conductive active material with small particle size, large solid electrolyte interfacial area, and low tortuosity in electrodes and separator.

\section{ACKNOWLEDGEMENTS}

This research at Oak Ridge National Laboratory, managed by UT Battelle, LLC, for the U.S. 
Department of Energy (DOE) under Contract DEAC05-00OR22725, was sponsored by the Office of Energy Efficiency and Renewable Energy (EERE) Vehicle Technologies Office (VTO) (Deputy Director: David Howell) Applied Battery Research subprogram (Program Manager: Peter Faguy). The U.S. government retains and the publisher, by accepting the article for publication, acknowledges that the U.S. government retains a nonexclusive, paid-up, irrevocable, worldwide license to publish or reproduce the published form of this article, or allow others to do so, for U.S. government purposes. The Department of Energy will provide public access to these results of federally sponsored research in accordance with the DOE Public Access Plan (http:// energy.gov/downloads/doe-public-access-plan).

\section{REFERENCES}

1. S.C. Davis, S.E. Williams, and R.G. Boundy, Transportation Energy Data Book: Edition 35. http://cta.ornl.gov/data/ download35.shtml. Accessed 2016.

2. M. Tran, D. Banister, J.D.K. Bishop, and M.D. McCulloch, Nat. Clim. Change 2, 328 (2012).

3. D. Howell, DOE Vehicle Technology Office Research and Development, US-China CERC-CVC Meeting, Lemont, IL, 2016. https://anl.app.box.com/s/10sm2q0i66w28baky0hhorv trgkgprbg. Accessed 2016.

4. J. Gainese, and R. Cuenza, Report ANL/ESD-42, Argonne National Laboratory, Argonne, IL, 2000. https://www.anl. gov/energy-systems/publication/costs-lithium-ion-bat teries-vehicles.

5. USABC, USABC Goals for Advanced Batteries for EVsCY2020. www.uscar.org/commands/files_download.php? files_id=364.

6. D. Howell, B. Cunningham, T. Duong, and P. Faguy, Overview of the DOE VTO Advanced Battery R\&D Program. https://energy.gov/sites/prod/files/2016/06/f32/es000_ howell_2016_o_web.pdf. Accessed 2016.

7. K. McCormac, I. Byrd, R. Brannen, B. Seymour, J. Li, and J. Wu, Phys. Status Solidi (A) 212, 877 (2015).

8. M.N. Obrovac and V.L. Chevrier, Chem. Rev. 114, 11444 (2014).

9. X. Su, Q. Wu, J. Li, X. Xiao, A. Lott, W. Lu, B.W. Sheldon, and J. Wu, Adv. Energy Mater. 4, 1300882 (2014).

10. K. Brandt, Solid State Ion. 69, 173 (1994).

11. S.J. Gerssen-Gondelach and A.P.C. Faaij, J. Power Sour. 212, 111 (2012).

12. J. Hong, S. Park, and N. Chang, in 2016 21st Asia and South Pacific Design Automation Conference (ASP-DAC). (2016), pp. 781-786.

13. P. Lamp, USA/Germany Workshop on Li-Ion-Cell Manufacturing for R\&D Needs, ULM, Germany, 2016.

14. D.L. Wood III, Roll-to-roll electrode processing and materials NDE for advanced lithium secondary batteries. https://energy.gov/eere/vehicles/downloads/roll-roll-electrodeprocessing-and-materials-nde-advanced-lithium-secondar-0. Accessed 2013.

15. J.C. Panitz and P. Novak, J. Power Sour. 97, 174 (2001).

16. R.E. Ruther, A.F. Callender, H. Zhou, S.K. Martha, and J. Nanda, J. Electrochem. Soc. 162, A98 (2015).

17. D. Mohanty, J. Li, R. Born, L.C. Maxey, R.B. Dinwiddie, C. Daniel, and D.L. Wood III, Anal. Methods 6, 674 (2014).

18. D. Mohanty, E. Hockaday, J. Li, D.K. Hensley, C. Daniel, and D.L. Wood, J. Power Sour. 312, 70 (2016).

19. P. Rupnowski, M. Ulsh, B. Sopori, B.G. Green, D.L. Wood III, J. Li, and Y. Sheng, National Renewable Energy Laboratory, unpublished research, 2017.

20. J. Li, B.L. Armstrong, J. Kiggans, C. Daniel, and D.L. Wood, J. Electrochem. Soc. 160, A201 (2013).
21. J. Li, C. Daniel, and D. Wood III, in Handbook of Battery Materials, eds. by C. Daniel, J.O. Besenhard (Wiley-VCH, Weinheim, 2011), p. 939.

22. D.L. Wood III, J. Li, and C. Daniel, J. Power Sour. 275, 234 (2015).

23. D.L. Wood III, J.D. Quass, J. Li, S. Ahmed, D. Ventola, and C. Daniel, Drying Technol. (2017). doi:10.1080/07373937. 2017.1319855.

24. J. Muthu and J. Battaglini, Battery Power Prod. Technol. 13,12 (2009).

25. M. Zackrisson, L. Avellán, and J. Orlenius, J. Cleaner Prod. 18, 1519 (2010).

26. J. Li, B. Armstrong, J. Kiggans, C. Daniel, and D. Wood III, Langmuir 28, 3783 (2012).

27. J. Li, C. Rulison, J. Kiggans, C. Daniel, and D.L. Wood III, J. Electrochem. Soc. 159, A1152 (2012).

28. Z. Du, K.M. Rollag, J. Li, S.J. An, M. Wood, Y. Sheng, P.P. Mukherjee, C. Daniel, and D.L. Wood III, J. Power Sour. 354, 200 (2017).

29. J. Li, C. Daniel, S.J. An, and D. Wood, MRS Adv. 1, 1029 (2016).

30. C.C. Li, J.T. Lee, and X.W. Peng, J. Electrochem. Soc. 153, A809 (2006).

31. C.C. Li, X.W. Peng, J.T. Lee, and F.M. Wang, J. Electrochem. Soc. 157, A517 (2010).

32. J. Li, B.L. Armstrong, C. Daniel, J. Kiggans, and D.L. Wood III, J. Colloid Interface Sci. 405, 118 (2013).

33. K.M. Kim, W.S. Jeon, I.J. Chung, and S.H. Chang, J. Power Sour. 83, 108 (1999).

34. G.-W. Lee, J.H. Ryu, W. Han, K.H. Ahn, and S.M. Oh, J. Power Sour. 195, 6049 (2010).

35. J.F. Martin, A. Yamada, G. Kobayashi, S.I. Nishimura, R. Kanno, D. Guyomard, and N. Dupre, Electrochem. Solid State Lett. 11, A12 (2008).

36. J. Zhou, Lishen Research Institute, 33rd International Battery, Fort Lauderdale, FL (2016).

37. N. Loeffler, J. von Zamory, N. Laszczynski, I. Doberdo, G.T. Kim, and S. Passerini, J. Power Sour. 248, 915 (2014).

38. J. Li, C. Daniel, D. Mohanty, and D.L. Wood III, Thick lowcost, high power lithium-ion electrodes via aqueous processing. https://energy.gov/sites/prod/files/2016/06/f32/es1 64_li_2016_o_web.pdf. Accessed 2016.

39. M.S. Tirumkudulu and W.B. Russel, Langmuir 21, 4938 (2005).

40. Z. Du, C.J. Janke, J. Li, C. Daniel, and D.L. Wood, J. Electrochem. Soc. 163, A2776 (2016).

41. C. Daniel, and M. Wixom, ORNL/TM-2012/617, Oak Ridge National Laboratory. https://www.osti.gov/scitech/servlets/ purl/1060885. Accessed 2012.

42. S.P. Pappas, Radiation Curing: Science and Technology (Boston: Springer, 1992), p. 1.

43. J.F. Kinstle, Radiation Curing of Polymeric Materials (Washington: American Chemical Society, 1990), p. 17.

44. K. Xu, Chem. Rev. 114, 11503 (2014).

45. K. Xu, Chem. Rev. 104, 4303 (2004).

46. S.J. An, J. Li, C. Daniel, D. Mohanty, S. Nagpure, and D.L. Wood, Carbon 105, 52 (2016).

47. S. Bhattacharya and A.T. Alpas, Carbon 50, 5359 (2012).

48. S. Bhattacharya, A.R. Riahi, and A.T. Alpas, MRS Proc. 1388, 1 (2012).

49. H.-H. Lee, Y.-Y. Wang, C.-C. Wan, M.-H. Yang, H.-C. Wu, and D.-T. Shieh, J. Power Sour. 134, 118 (2004).

50. S.J. An, J. Li, Z. Du, C. Daniel, and D.L. Wood, J. Power Sour. 342, 846 (2017).

51. J. Rafiee, X. Mi, H. Gullapalli, A.V. Thomas, F. Yavari, Y. Shi, P.M. Ajayan, and N.A. Koratkar, Nat. Mater. 11, 217 (2012).

52. A.M. Colclasure, K.A. Smith, and R.J. Kee, Electrochim. Acta 58, 33 (2011).

53. J. Collins, G. Gourdin, M. Foster, and D. Qu, Carbon 92, 193 (2015).

54. J.C. Ye, S. Charnvanichborikarn, M.A. Worsley, S.O. Kucheyev, B.C. Wood, and Y.M. Wang, Carbon 85, 269 (2015). 
55. Y.P. Wu, C. Jiang, C. Wan, and R. Holze, Solid State Ion. 156, 283 (2003).

56. Y. Zhan, B. Zhang, L. Cao, X. Wu, Z. Lin, X. Yu, X. Zhang, D. Zeng, F. Xie, W. Zhang, J. Chen, and H. Meng, Carbon 94, 1 (2015).

57. Y. Wu, C. Jiang, C. Wan, and E. Tsuchida, Electrochem. Commun. 2, 272 (2000).

58. A.J. Loebl, C.J. Oldham, C.K. Devine, B. Gong, S.E. Atanasov, G.N. Parsons, and P.S. Fedkiw, J. Electrochem. Soc. 160, A1971 (2013).

59. M.E. Spahr, H. Wilhelm, F. Joho, J.-C. Panitz Jr., J. Wambach, P. Novák, and N. Dupont-Pavlovsky, J. Electrochem. Soc. 149, A960 (2002).

60. J.U.P. Novák, H. Buqa, F. Krumeich, M.E. Spahr, D. Goers, H. Wilhelm, J. Dentzer, R. Gadiou, and C. Vix-Guterl, J. Electrochem. Soc. 174, 1082 (2007).

61. Y. Ein-Eli and V.R. Koch, J. Electrochem. Soc. 144, 2968 (1997)

62. S.J. An, J. Li, Y. Sheng, C. Daniel, and D.L. Wood III, J. Electrochem. Soc. 163, A2866 (2016).

63. K.E. Thomas-Alyea and J. Newman, Electrochem. Syst., 3rd ed. (New York: Wiley, 2004).

64. M. Doyle, T.F. Fuller, and J. Newman, J. Electrochem. Soc. 140, 1526 (1993).

65. S. Yu, S. Kim, T.Y. Kim, J.H. Nam, and W.I. Cho, Bull. Korean Chem. Soc. 34, 79 (2013).

66. K.G. Gallagher, S.E. Trask, C. Bauer, T. Woehrle, S.F. Lux, M. Tschech, P. Lamp, B.J. Polzin, S. Ha, B. Long, Q. Wu, W. Lu, D.W. Dees, and A.N. Jansen, J. Electrochem. Soc. 163, A138 (2016).

67. Y. Dai and V. Srinivasan, J. Electrochem. Soc. 163, A406 (2016).

68. Z. Du, D.L. Wood, C. Daniel, S. Kalnaus, and J. Li, J. Appl. Electrochem. 47, 405 (2017).

69. B. Tjaden, S.J. Cooper, D.J.L. Brett, D. Kramer, and P.R. Shearing, Curr. Opin. Chem. Eng. 12, 44 (2016).

70. N. Ogihara, Y. Itou, T. Sasaki, and Y. Takeuchi, J. Phys. Chem. C 119, 4612 (2015)

71. F.M. Jiang and P. Peng, Sci. Rep. 6, 26532 (2016).

72. C.-J. Bae, C.K. Erdonmez, J.W. Halloran, and Y.-M. Chiang, Adv. Mater. 25, 1254 (2013).

73. Y. Xu, M. Zhou, and Y. Lei, Adv. Energy Mater. 6, 1502514 (2016).

74. Y.G. Guo, Y.S. Hu, W. Sigle, and J. Maier, Adv. Mater. 19, 2087 (2007).

75. B. Fang, M.S. Kim, J.H. Kim, S. Lim, and J.S. Yu, J. Mater. Chem. 20, 10253 (2010).

76. Y.S. Hu, P. Adelhelm, B.M. Smarsly, S. Hore, M. Antonietti, and J. Maier, Adv. Funct. Mater. 17, 1873 (2007).

77. V. Srinivasan and J. Newman, J. Electrochem. Soc. 151, A1517 (2004).

78. C. Huang, N.P. Young, J. Zhang, H.J. Snaith, and P.S. Grant, Nano Energy 31, 377 (2017).

79. D.-W. Chung, M. Ebner, D.R. Ely, V. Wood, and R.E. García, Model. Simul. Mater. Sci. Eng. 21, 074009 (2013).

80. J.S. Sander, R.M. Erb, L. Li, A. Gurijala, and Y.M. Chiang, Nat. Energy 1, 16099 (2016).

81. M. Mangang, H.J. Seifert, and W. Pfleging, J. Power Sour. 304, 24 (2016).

82. C.L. Cobb and M. Blanco, J. Power Sour. 249, 357 (2014).

83. K. Sun, T.-S. Wei, B.Y. Ahn, J.Y. Seo, S.J. Dillon, and J.A. Lewis, Adv. Mater. 25, 4539 (2013).

84. H. Buqa, D. Goers, M. Holzapfel, M.E. Spahr, and P. Novak, J. Electrochem. Soc. 152, A474 (2005).

85. N. Nitta, F.X. Wu, J.T. Lee, and G. Yushin, Mater. Today $18,252(2015)$

86. C. Daniel and J.O. Besenhard, Handbook of Battery Materials (Weinheim: Wiley, 2011).

87. C. Daniel, D. Mohanty, J. Li, and D.L. Wood, Review on Electrochemical Storage Materials and Technology, ed. D.C. Meyer and T. Leisegang (American Inst Physics: Melville, 2014), pp. 26-43

88. B.L. Ellis, K.T. Lee, and L.F. Nazar, Chem. Mater. 22, 691 (2010).
89. D. Andre, S.J. Kim, P. Lamp, S.F. Lux, F. Maglia, O. Paschos, and B. Stiaszny, J. Mater. Chem. A 3, 6709 (2015).

90. J.B. Goodenough, and K. Mizuchima, Patent No. US4302518A, Nov 241981.

91. K. Mizushima, P.C. Jones, P.J. Wiseman, and J.B. Goodenough, Mater. Res. Bull. 15, 783 (1980).

92. Z.H. Chen, Z.H. Lu, and J.R. Dahn, J. Electrochem. Soc. 149, A1604 (2002).

93. J.R. Dahn, U. Vonsacken, and C.A. Michal, Solid State Ion. 44, 87 (1990)

94. T. Ohzuku and Y. Makimura, Chem. Lett. 8, 744 (2001).

95. T. Ohzuku and Y. Makimura, Chem. Lett. 7, 642 (2001).

96. Y.K. Sun, D.H. Kim, C.S. Yoon, S.T. Myung, J. Prakash, and K. Amine, Adv. Funct. Mater. 20, 485 (2010).

97. H.J. Noh, S. Youn, C.S. Yoon, and Y.K. Sun, J. Power Sour. 233,121 (2013).

98. K.G. Gallagher, S. Goebel, T. Greszler, M. Mathias, W. Oelerich, D. Eroglu, and V. Srinivasan, Energy Environ. Sci. 7, 1555 (2014)

99. J.A. Gilbert, J. Bareño, T. Spila, S.E. Trask, D.J. Miller, B.J. Polzin, A.N. Jansen, and D.P. Abraham, J. Electrochem. Soc. 164, A6054 (2017).

100. F. Lin, I.M. Markus, D. Nordlund, T.C. Weng, M.D. Asta, H.L.L. Xin, and M.M. Doeff, Nat. Commun. 5, 3529 (2014).

101. W. Liu, P. Oh, X. Liu, M.J. Lee, W. Cho, S. Chae, Y. Kim, and J. Cho, Angew. Chem. Int. Edit. 54, 4440 (2015).

102. M. Gauthier, T.J. Carney, A. Grimaud, L. Giordano, N. Pour, H.H. Chang, D.P. Fenning, S.F. Lux, O. Paschos, C. Bauer, F. Magia, S. Lupart, P. Lamp, and Y. Shao-Horn, J. Phys. Chem. Lett. 6, 4653 (2015).

103. H.B. Rong, M.Q. Xu, Y.M. Zhu, B.Y. Xie, H.B. Lin, Y.H. Liao, L.D. Xing, and W.S. Li, J. Power Sour. 332, 312 (2016).

104. L.W. Liang, F. Jiang, Y.B. Cao, G.R. Hu, K. Du, and Z.D. Peng, J. Power Sour. 328, 422 (2016).

105. I.M. Markus, F. Lin, K.C. Kam, M. Asta, and M.M. Doeff, J. Phys. Chem. Lett. 5, 3649 (2014).

106. D. Mohanty, K. Dahlberg, D.M. King, L.A. David, A.S. Sefat, D.L. Wood, C. Daniel, S. Dhar, V. Mahajan, M. Lee, and F. Albano, Sci. Rep. 6, 26532 (2016).

107. J.Y. Liao and A. Manthiram, J. Power Sour. 282, 429 (2015).

108. N.S. Choi, J.G. Han, S.Y. Ha, I. Park, and C.K. Back, RSC Adv. 5, 2732 (2015).

109. X.W. Zheng, X.S. Wang, X. Cai, L.D. Xing, M.Q. Xu, Y.H Liao, X.P. Li, and W.S. Li, A.C.S. Appl. Mater. Interfaces 8, 30116 (2016).

110. Z. Cao, Y. Li, M. Shi, G. Zhu, R. Zhang, X. Li, H. Yue, and S. Yang, J. Electrochem. Soc. 164, A475 (2017).

111. J.R. Croy, A. Abouimrane, and Z. Zhang, MRS Bull. 39, 407 (2014).

112. J.Y. Liao, S.M. Oh, and A. Manthiram, A.C.S. AppL. Mater. Interfaces 8, 24543 (2016).

113. Y.K. Sun, S.T. Myung, B.C. Park, J. Prakash, I. Belharouak, and K. Amine, Nat. Mater. 8, 320 (2009).

114. B.B. Lim, S.J. Yoon, K.J. Park, C.S. Yoon, S.J. Kim, J.J. Lee, and Y.K. Sun, Adv. Funct. Mater. 25, 4673 (2015).

115. U.-H. Kim, E.-J. Lee, C.S. Yoon, S.-T. Myung, and Y.-K. Sun, Adv. Energy Mater. 6, 1601417 (2016).

116. B.-B. Lim, S.-T. Myung, C.S. Yoon, and Y.-K. Sun, ACS Energy Lett. 1, 283 (2016).

117. J. Wang, C. Du, X. Xu, X. He, G. Yin, Y. Ma, P. Zuo, X. Cheng, and Y. Gao, Electrochim. Acta 192, 340 (2016).

118. M.M. Thackeray, S.H. Kang, C.S. Johnson, J.T. Vaughey, R. Benedek, and S.A. Hackney, J. Mater. Chem. 17, 3112 (2007)

119. D. Mohanty, A. Huq, E.A. Payzant, A.S. Sefat, J. Li, D.P. Abraham, D.L. Wood, and C. Daniel, Chem. Mater. 25, 4064 (2013)

120. K.A. Jarvis, Z.Q. Deng, L.F. Allard, A. Manthiram, and P.J. Ferreira, Chem. Mater. 23, 3614 (2011).

121. S.K. Martha, J. Nanda, G.M. Veith, and N.J. Dudney, J. Power Sour. 199, 220 (2012). 
122. J.R. Croy, M. Balasubramanian, K.G. Gallagher, and A.K. Burrell, Acct. Chem. Res. 48, 2813 (2015).

123. L. Baggetto, D. Mohanty, R.A. Meisner, C.A. Bridges, C. Daniel, D.L. Wood, N.J. Dudney, and G.M. Veith, $R S C$ Adv. 4, 23364 (2014).

124. D. Mohanty, S. Kalnaus, R.A. Meisner, K.J. Rhodes, J. Li, E.A. Payzant, D.L. Wood, and C. Daniel, J. Power Sour. 229, 239 (2013).

125. D. Mohanty, S. Kalnaus, R.A. Meisner, A.S. Safat, J. Li, E.A. Payzant, K. Rhodes, D.L. Wood, and C. Daniel, RSC Adv. 3, 7479 (2013).

126. D. Mohanty, J. Li, D.P. Abraham, A. Huq, E.A. Payzant, D.L. Wood, and C. Daniel, Chem. Mater. 26, 6272 (2014).

127. D. Mohanty, A.S. Sefat, S. Kalnaus, J. Li, R.A. Meisner, E.A. Payzant, D.P. Abraham, D.L. Wood, and C. Daniel, J. Mater. Chem. A 1, 6249 (2013).

128. D. Mohanty, A.S. Sefat, J. Li, R.A. Meisner, A.J. Rondinone, E.A. Payzant, D.P. Abraham, D.L. Wood, and C. Daniel, Phys. Chem. Chem. Phys. 15, 19496 (2013).

129. D. Mohanty, A.S. Sefat, E.A. Payzant, J. Li, D.L. Wood, and C. Daniel, J. Power Sour. 283, 423 (2015).

130. A. Birrozzi, N. Laszczynski, M. Hekmatfar, J. von Zamory, G.A. Giffin, and S. Passerini, J. Power Sour. 325, 525 (2016).

131. J.-G. Han, I. Park, J. Cha, S. Park, S. Park, S. Myeong, W. Cho, S.-S. Kim, S.Y. Hong, J. Cho, and N.-S. Choi, ChemElectroChem 4, 56 (2017).

132. X.F. Zhang, I. Belharouak, L. Li, Y. Lei, J.W. Elam, A.M. Nie, X.Q. Chen, R.S. Yassar, and R.L. Axelbaum, Adv. Energy Mater. 3, 1299 (2013).

133. Q.Q. Qiao, H.Z. Zhang, G.R. Li, S.H. Ye, C.W. Wang, and X.P. Gao, J. Mater. Chem. A 1, 5262 (2013).

134. S.K. Martha, J. Nanda, Y. Kim, R.R. Unocic, S. Pannala, and N.J. Dudney, J. Mater. Chem. A 1, 5587 (2013).

135. I. Bloom, L. Trahey, A. Abouimrane, I. Belharouak, X.F. Zhang, Q.L. Wu, W.Q. Lu, D.P. Abraham, M. Bettge, J.W. Elam, X.B. Meng, A.K. Burrell, C.M. Ban, R. Tenent, J. Nanda, and N. Dudney, J. Power Sour. 249, 509 (2014).

136. A. Ito, D.C. Li, Y. Sato, M. Arao, M. Watanabe, M. Hatano, H. Horie, and Y. Ohsawa, J. Power Sour. 195, 567 (2010).

137. Q. Li, G.S. Li, C.C. Fu, D. Luo, J.M. Fan, and L.P. Li, A.C.S. Appl. Mater. Interfaces 6, 10330 (2014).

138. J. Lin, D.B. Mu, Y. Jin, B.R. Wu, Y.F. Ma, and F. Wu, J. Power Sour. 230, 76 (2013).

139. J.R. Croy, J.S. Park, Y. Shin, B.T. Yonemoto, M. Balasubramanian, B.R. Long, Y. Ren, and M.M. Thackeray, J. Power Sour. 334, 213 (2016).

140. X.P. Gao and H.X. Yang, Energy Environ. Sci. 3, 174 (2010).

141. S.S. Zhang, J. Power Sour. 231, 153 (2013).
142. H. Zhou, R.E. Ruther, J. Adcock, W. Zhou, S. Dai, and J. Nanda, ACS Nano 9, 2530 (2015).

143. Y.L. Liang, Z.L. Tao, and J. Chen, Adv. Energy Mater. 2 , $742(2012)$.

144. J. Lee, A. Urban, X. Li, D. Su, G. Hautier, and G. Ceder, Science 343, 519-522 (2014).

145. D.H. Seo, J. Lee, A. Urban, R. Malik, S. Kang, and G. Ceder, Nat. Chem. 8, 692 (2016).

146. C. Masquelier and L. Croguennec, Chem. Rev. 113, 6552 (2013).

147. J.R. Dahn, T. Zheng, Y.H. Liu, and J.S. Xue, Science 270, 590 (1995).

148. M.T. McDowell, S.W. Lee, W.D. Nix, and Y. Cui, Adv. Mater. 25, 4966 (2013).

149. I.A. Courtney and J.R. Dahn, J. Electrochem. Soc. 144 2045 (1997).

150. D. Billaud, E. McRae, and A. Herold, Mater. Res. Bull. 14, 857 (1979).

151. M.T. McDowell, S.W. Lee, I. Ryu, H. Wu, W.D. Nix, J.W. Choi, and Y. Cui, Nano Lett. 11, 4018 (2011).

152. J.P. Maranchi, A.F. Hepp, A.G. Evans, N.T. Nuhfer, and P.N. Kumta, J. Electrochem. Soc. 153, A1246 (2006).

153. J.O. Besenhard, J. Yang, and M. Winter, J. Power Sour. 68, 87 (1997).

154. I.A. Courtney, W.R. McKinnon, and J.R. Dahn, J. Electrochem. Soc. 146, 59 (1999).

155. N. Dimov, S. Kugino, and A. Yoshio, J. Power Sour. 136, 108 (2004).

156. M. Karulkar, R. Blaser, and B. Kudla, J. Power Sour. 273, 1194 (2015).

157. J.Y. Eom, J.W. Park, H.S. Kwon, and S. Rajendran, J. Electrochem. Soc. 153, A1678 (2006).

158. S.M. Zhu, C.L. Zhu, J. Ma, Q. Meng, Z.P. Guo, Z.Y. Yu, T. $\mathrm{Lu}, \mathrm{Y}$. Li, D. Zhang, and W.M. Lau, RSC Adv. 3, 6141 (2013).

159. N. Kim, C. Oh, J. Kim, J.-S. Kim, E.D. Jeong, J.-S. Bae, T.E. Hong, and J.K. Lee, J. Electrochem. Soc. 164, A6075 (2017).

160. A. Mauger, H.M. Xie, and C.M. Julien, AIMS Mater. Sci. 3, 1054 (2016).

161. J.J. Wang, T.T. Xu, X. Huang, H. Li, and T.L. Ma, RSC Adv. 6, 87778 (2016).

162. V. Etacheri, O. Haik, Y. Goffer, G.A. Roberts, I.C. Stefan, R. Fasching, and D. Aurbach, Langmuir 28, 965 (2012).

163. R. Jung, M. Metzger, D. Haering, S. Solchenbach, C. Marino, N. Tsiouvaras, C. Stinner, and H.A. Gasteiger, J. Electrochem. Soc. 163, A1705 (2016).

164. I. Byrd, H. Chen, T. Webber, J. Li, and J. Wu, RSC Adv. 5, 92878 (2015)

165. H. Tian, F. Xin, X. Wang, W. He, and W. Han, J. Materiomics 1, 153 (2015). 